\title{
Type 3 autoimmune polyendocrine syndrome (APS) diagnosed in an 87-year-old patient with a concomitant chronic autoimmune urticaria
}

\author{
Autoimmunologiczny zespół niedoczynności wielogruczołowej typu 3 \\ rozpoznany u 87-letniej pacjentki ze współistnieniem przewlekłej pokrzywki \\ autoimmunologicznej
}

Magdalena Kutwin, Klaudia Orłowska-Orlik, Jarosław Bogaczewicz, Anna Woźniacka

Department of Dermatology and Venereology, Medical University of Lodz, Poland

Klinika Dermatologii i Wenerologii Uniwersytetu Medycznego w Łodzi, Polska

\section{CORRESPONDING AUTHOR/} ADRES DO KORESPONDENCJI: lek. Klaudia Orłowska-Orlik Klinika Dermatologii i Wenerologii Uniwersytet Medyczny w Łodzi pl. Hallera 1, bud. 6 90-647 Łódź tel.: +48 889204826 e-mail: klaudia.o@wp.pl

\begin{abstract}
Introduction. Autoimmune polyendocrine syndromes constitute a group of diseases with a diverse clinical picture, and a common aetiology associated with autoreactive mechanisms. Four basic types of the disease have been specified. Type 3 autoimmune polyendocrine syndrome includes co-existence of autoimmune thyroid disease with at least one of the following: type 1 diabetes, leucoderma, alopecia areata, chronic atrophic gastritis, or myasthenia.
\end{abstract}

Objective. To describe type 3 autoimmune polyendocrine syndrome diagnosed in a patient admitted to the hospital due to chronic urticaria.

Case report. An 87-year-old female patient was admitted to Dermatology and Venereology Clinic to determine the cause and modify the treatment for chronic urticaria. Physical examination revealed disseminated urticarial nodules, depigmentation lesions covering about $98 \%$ of the body surface, and alopecia areata of the scalp. Furthermore, hypothyroidism and malignant anaemia were confirmed. The patient was diagnosed with type 3 autoimmune polyendocrine syndrome.

Conclusions. Not only does the ability to diagnose the described disease unit have a cognitive value, but it also enables diagnosing and treating concomitant autoimmune diseases.

\section{STRESZCZENIE}

Wprowadzenie. Autoimmunologiczne zespoły niedoczynności wielogruczołowej to grupa schorzeń o zróżnicowanym obrazie klinicznym, ale o wspólnej etiologii związanej z mechanizmami autoreaktywnymi. Wyodrębniono cztery podstawowe typy choroby. Autoimmunologiczny zespół niedoczynności wielogruczołowej typu 3 obejmuje współwystępowanie autoimmunologicznej choroby tarczycy $\mathrm{z}$ co najmniej jednym z następujących schorzeń: cukrzyca typu 1, bielactwo, łysienie plackowate, przewlekłe zanikowe zapalenie błony śluzowej żołądka, miastenia.

Cel pracy. Omówienie przypadku autoimmunologicznego zespołu niedoczynności wielogruczołowej typu 3 rozpoznanego u pacjentki przyjętej do szpitala z powodu pokrzywki przewlekłej. 
Opis przypadku. Kobieta 87-letnia została przyjęta do Kliniki Dermatologii i Wenerologii w celu ustalenia przyczyny i modyfikacji leczenia pokrzywki przewlekłej. Przedmiotowo, oprócz rozsianych bąbli pokrzywkowych, stwierdzono zmiany depigmentacyjne obejmujące ok. 98\% powierzchni ciała oraz łysienie plackowate skóry owłosionej głowy. Ponadto wykazano niedoczynność tarczycy i niedokrwistość złośliwą. U chorej rozpoznano autoimmunologiczny zespół niedoczynności wielogruczołowej typu 3.

Wnioski. Umiejętność diagnozowania omówionej jednostki chorobowej nie tylko ma wartość poznawczą, lecz także umożliwia wcześniejsze rozpoznawanie oraz leczenie współistniejących chorób autoimmunizacyjnych.

Key words: autoimmune polyendocrine syndrome, APS, APS-3.

Słowa kluczowe: autoimmunologiczny zespół niedoczynności wielogruczołowej, APS, APS-3.

\section{INTRODUCTION}

Autoimmune polyendocrine syndromes (APSs) are a heterogeneous group of diseases characterized by dysfunctions of not only incretory glands, but also other organs [1-6]. Current APS classification based on diverse clinical picture was formulated by Neufeld et al. [7] (table 1). There are four basic types of the syndrome, whose common denominator is an autoimmune basis. Although the disease's cause is not fully known, it is known that in genetically predisposed individuals production of organ-specific antibodies begins $[1,2,8,9]$. Developing immune complexes initiate the development of chronic inflammation, which in turn leads to organ dysfunctions.

In case of APS-1 a triad of symptoms should be expected: chronic candidiasis of the mucosa, hypoparathyroidism and hypocorticoidism; however, two out of the above three symptoms suffice to diagnose this

\section{WPROWADZENIE}

Autoimmunologiczne zespoły niedoczynności wielogruczołowej (autoimmune polyendocrine syndromes - APSs) to heterogenna grupa schorzeń charakteryzujących się dysfunkcją nie tylko gruczołów dokrewnych, lecz także innych narządów [1-6]. Aktualna klasyfikacja APS oparta na zróżnicowanym obrazie klinicznym została sformułowana przez Neufelda i wsp. [7] (tab. 1). Wyróżnia się cztery podstawowe typy zespołu, których wspólnym mianownikiem jest podłoże autoimmunologiczne. Chociaż przyczyna choroby nie jest w pełni poznana, to jednak wiadomo, że u osób predysponowanych genetycznie dochodzi do zapoczątkowania produkcji swoistych narządowo przeciwciał $[1,2,8,9]$. Tworzące się kompleksy immunologiczne inicjują rozwój przewlekłego stanu zapalnego, który prowadzi do dysfunkcji narządowej.

Table I. Characteristic features of type I-4 autoimmune polyendocrine syndromes

Tabela I. Charakterystyka autoimmunologicznych zespołów niedoczynności wielogruczołowej typu I-4

\begin{tabular}{ll} 
APS type/Typ APS & Characteristics/Charakterystyka \\
\hline I & At least two diseases from the following: chronic mucosal candidiasis, autoimmune hypoparathyroidism, \\
autoimmune hypocorticoidism/ \\
Co najmniej 2 z wymienionych schorzeń: przewlekła kandydoza błon śluzowych, autoimmunologiczna \\
niedoczynność przytarczyc, autoimmunologiczna niedoczynność kory nadnerczy
\end{tabular}


syndrome. Moreover, according to various sources the broad spectrum of the disease includes also autoimmune hepatitis, type 1 diabetes, hypothyroidism, hypogonadism, malignant anaemia, asplenism, and alopecia areata $[1,3,8,10,11]$. APS-2 type (Schmidt's syndrome) is the most common APS phenotype. Concomitance of Addison's disease and autoimmune thyroiditis is also typical; moreover, the patients may develop myasthenia, celiac syndrome, leucoderma, polyserositis, alopecia areata, hypogonadism, IgA deficiency, Parkinson's disease, and type 1 diabetes $[1,3,12,13]$. A type APS-3 may be diagnosed in a patient that does not have confirmed functional disorders of adrenocortical glands as opposed to type 1 and type 2. The presence of the following is of key importance: autoimmune thyroiditis concomitant with type 1 diabetes, leucoderma, alopecia areata, chronic atrophic gastritis, or myasthenia $[3,5,6]$. Other combinations of autoimmune diseases that are not included in the above classifications fall within the scope of APS-4 [3, 14].

\section{OBJECTIVE}

To discuss a case of a female patient that was admitted to the hospital in order to undergo diagnostics and treatment of chronic urticaria, and was diagnosed with APS-3 during hospitalization.

\section{CASE REPORT}

An 87-year-old female patient was admitted to the Clinic in order to determine aetiology and modify the treatment of chronic urticaria. First urticarial nodules appeared 15 years ago, however, in the meantime remission lasting for even a couple of months were observed. During exacerbation periods there appeared angioedema of eyelids and lips. In such cases, oral prednisolone was used in gradually decreasing doses (from $30 \mathrm{mg} /$ day) and antihistamine drugs (levocetirizine, fexofenadine), which led to clinical improvements. Urticarial diet applied for a couple of weeks did not exert an influence on intensification of clinical symptoms. Current period of exacerbation persisted for about a month before the hospitalization. Aetiological factor could not be grasped. The patient denied having been using new drugs (including nonsteroidal anti-inflammatory drugs), dietary supplements, and having been exposed to toxic factors. Existing treatment with antihistamine preparations (levocetirizine $10 \mathrm{mg}$ / day and fexofenadine $240 \mathrm{mg}$ / day) on an outpatient basis did not lead to disappearance of urticarial nodules. The patient confirmed a history of arterial hypertension that was stable and responded to treatment (for about 20 years; for a cou-
W przypadku APS-1 należy się spodziewać triady objawów: przewlekłej kandydozy śluzówek, niedoczynności przytarczyc i kory nadnerczy, jednak do rozpoznania wystarczą 2 spośród 3 wymienionych. Szerokie spektrum schorzenia obejmuje także, według różnych źródeł, autoimmunologiczne zapalenie wątroby, cukrzycę typu 1, niedoczynność tarczycy, hipogonadyzm, anemię złośliwą, asplenizm, łysienie plackowate $[1,3,8,10,11]$. Typ APS-2 (zespół Schmidta) jest najczęstszym fenotypem APS. Charakterystyczne jest współwystępowanie choroby Addisona i autoimmunologicznego zapalenia tarczycy, ponadto u chorych może się rozwinąć miastenia, celiakia, bielactwo, zapalenie błon surowiczych, łysienie plackowate, hipogonadyzm, niedobór IgA, choroba Parkinsona, cukrzyca typu 1 [1, 3, 12, 13]. Podtyp APS-3 można rozpoznać u pacjenta, u którego nie stwierdza się zaburzeń czynności kory nadnerczy, w przeciwieństwie do typu 1 i 2 . Ważna jest obecność autoimmunologicznego zapalenia tarczycy współistniejąca z cukrzycą typu 1, bielactwem, łysieniem plackowatym, przewlekłym zanikowym zapaleniem błony śluzowej żołądka lub miastenią $[3,5,6]$. Pozostałe połączenia schorzeń autoimmunologicznych, nieujęte w powyższych klasyfikacjach, mieszczą się w zakresie APS-4 [3, 14].

\section{CEL PRACY}

Omówienie przypadku pacjentki, która została przyjęta do szpitala w celu rozpoznania i leczenia pokrzywki przewlekłej, a w trakcie hospitalizacji rozpoznano APS-3.

\section{OPIS PRZYPADKU}

Pacjentka, lat 87, została przyjęta do kliniki w celu ustalenia etiologii i modyfikacji leczenia pokrzywki przewlekłej. Pierwsze wysiewy bąbli pokrzywkowych wystąpiły przed 15 laty, jednak w tym czasie obserwowano trwające nawet kilka lat remisje. W czasie nasilenia zmian występował obrzęk naczynioruchowy powiek i warg. Wówczas stosowano doustnie prednizolon w stopniowo zmniejszających się dawkach (od $30 \mathrm{mg} /$ dobę) oraz leki przeciwhistaminowe (lewocetyryzyna, feksofenadyna), które spowodowały poprawę kliniczną. Kilkutygodniowe stosowanie diety aspirynowej nie miało wpływu na nasilenie objawów klinicznych. Zaostrzenie utrzymywało się od około miesiąca przed hospitalizacją. Czynnik etiologiczny nie był uchwytny. Chora negowała stosowanie nowych leków (w tym niesteroidowych leków przeciwzapalnych), suplementów diety, narażenie na czynniki toksyczne. Dotychczasowe leczenie preparatami przeciwhistaminowymi (lewo- 
ple of years it was treated with enalapril $10 \mathrm{mg} /$ day, metoprolol $47.5 \mathrm{mg} /$ day, and indapamide $1.5 \mathrm{mg} /$ day), autoimmune hypothyroidism (confirmed with the presence of anti-thyroid antibodies; current supplementation with levothyroxine in alternate doses of 75 and $100 \mu \mathrm{g} /$ day), status post partial strumectomy that took place 50 years ago (probably due to a goitre; no medical documentation), hyperlipaemia (treated with simvastatin $20 \mathrm{mg}$ / day), nephrosclerosis of the right kidney, gastroesophageal reflux, anaemia due to vitamin $B_{12}$ deficiency (Addison-Biermer anaemia confirmed by the presence of antibodies against acid cells and internal factor; during vitamin $\mathrm{B}_{12}$ supplementation in the dose of $1,000 \mu \mathrm{g} /$ month), acquired leucoderma (for about 35 years), and alopecia areata (for about 50 years). Family history for dermatological diseases and autoimmune diseases was negative.

During the physical examination of the patient, no significant abnormalities were confirmed. Upon admission, superficial and slightly elevated urticarial nodules were present; they were of pale pink colour and with the diameter from 2 to about $5 \mathrm{~cm}$. The exanthemata were scattered on the smooth skin of the torso as well as upper and lower limbs (fig. 1). The most intensified lesions were confirmed on the frontal surface of the torso (abdomen) and extensor surfaces of the limbs. Moreover, depigmentation lesions covered $98 \%$ of the body surface - the only area where the pigmentation was preserved was the skin of the buttocks (fig. 2). On the scalp there was visible general hair thinning with several foci of alopecia areata in the frontal and occipital areas with the diameter of about 3-4 cm (fig. 3). Nail plates of fingers and toes as well as the oral mucosa with no pathological lesions.

Laboratory tests confirmed elevated concentration of C-reactive protein $(6.9 \mathrm{mg} / 1$ with the norm being up to $5.0 \mathrm{mg} / \mathrm{l})$, presence of antibodies against thy-

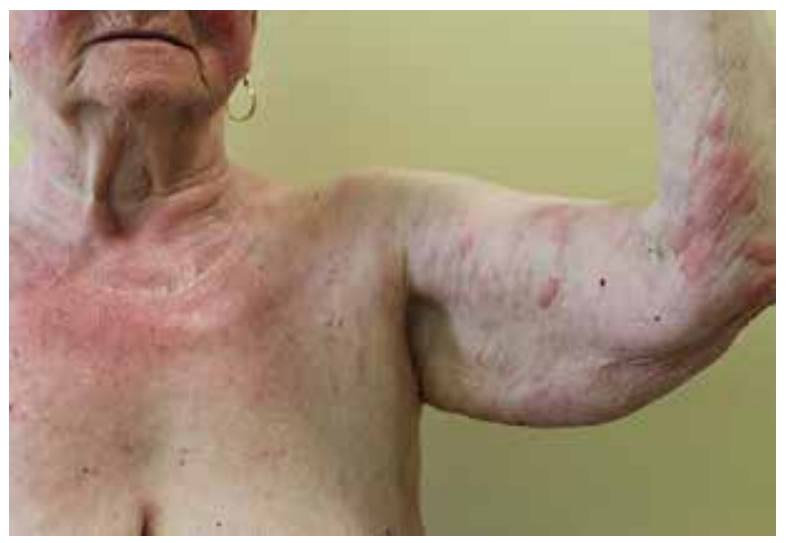

Figure I. Urticarial lesions localized on the skin of inside surfaces of the upper limbs

Rycina I. Bąble pokrzywkowe zlokalizowane na skórze wewnętrznej powierzchni kończyn górnych cetyryzyna w dawce $10 \mathrm{mg} /$ dobę i feksofenadyna w dawce $240 \mathrm{mg} /$ dobę) w warunkach ambulatoryjnych nie spowodowało ustąpienia bąbli pokrzywkowych. W wywiadzie pacjentka podawała stabilne i poddające się terapii nadciśnienie tętnicze (od ok. 20 lat, od kilku lat leczone enalaprylem w dawce $10 \mathrm{mg} /$ dobę, metoprololem $\mathrm{w}$ dawce $47,5 \mathrm{mg} /$ dobę $\mathrm{i}$ indapamidem $\mathrm{w}$ dawce $1,5 \mathrm{mg} /$ dobę), autoimmunologiczną niedoczynność tarczycy (potwierdzoną obecnością przeciwciał przeciwtarczycowych, obecnie $\mathrm{w}$ trakcie suplementacji lewotyroksyną $\mathrm{w}$ dawce naprzemiennie 75 i $100 \mu \mathrm{g} /$ dobę), stan po częściowej strumektomii przed 50 laty (najprawdopodobniej z powodu wola, brak dokumentacji medycznej), hiperlipidemię (leczona simwastatyną w dawce $20 \mathrm{mg}$ /dobę), marskość nerki prawej, refluks żołądkowo-przełykowy, niedokrwistość z niedoboru witaminy $\mathrm{B}_{12}$ (niedokrwistość Addisona-Biermera, potwierdzona obecnością przeciwciał przeciwko komórkom okładzinowym żołądka i przeciwko czynnikowi wewnętrznemu, w trakcie suplementacji witaminą $B_{12}$ w dawce $1000 \mu \mathrm{g} /$ miesiąc), bielactwo nabyte (od ok. 35 lat) oraz łysienie plackowate (od ok. 50 lat). Wywiad rodzinny w kierunku chorób dermatologicznych oraz schorzeń o podłożu autoimmunologicznym był negatywny.

Podczas badania internistycznego u chorej nie stwierdzono istotnych nieprawidłowości. Przy przyjęciu na skórze obecne były płaskowyniosłe bąble pokrzywkowe barwy bladoróżowej o średnicy od $2 \mathrm{~cm}$ do ok. $5 \mathrm{~cm}$. Wykwity były rozsiane na skórze gładkiej tułowia oraz kończyn górnych i dolnych (ryc. 1). Największe nasilenie zmian stwierdzono na przedniej powierzchni tułowia (brzuch) i na wyprostnych powierzchniach kończyn. Ponadto zmiany depigmentacyjne obejmowały $98 \%$ powierzchni skóry - jedynym obszarem, gdzie barwnik był zachowany, była skóra pośladków (ryc. 2). W obrębie skóry

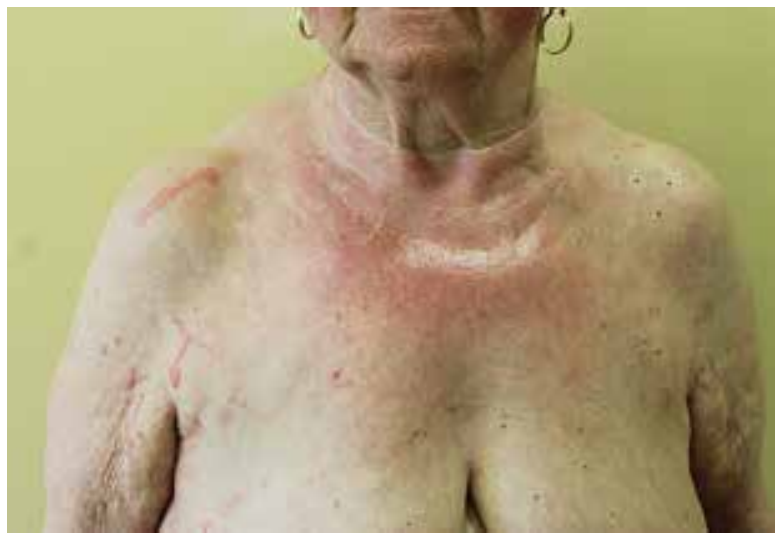

Figure 2. Hypopigmented lesions covering about $98 \%$ of the body surface

Rycina 2. Odbarwienia skóry obejmujące ok. 98\% powierzchni ciała 


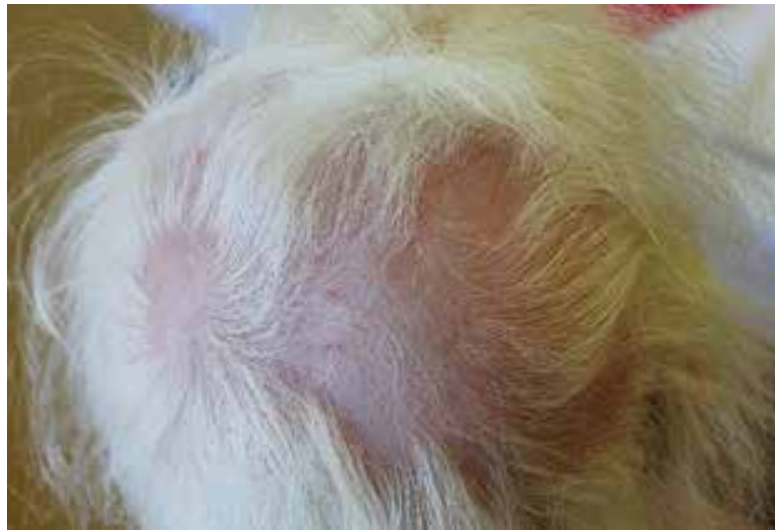

Figure 3. Alopecia areata foci found on the scalp

Rycina 3. Ogniska łysienia plackowatego w obrębie skóry owłosionej głowy

roid peroxidise (anti-TPO $84.8 \mathrm{IU} / \mathrm{ml}$ with the norm being up to $34.0 \mathrm{IU} / \mathrm{ml})$, and antibodies against acid cells and internal factor $(++)$. Presence of antibodies against thyroglobulin (anti-TG $106.03 \mathrm{IU} / \mathrm{ml}$ with the norm being up to $115 \mathrm{IU} / \mathrm{ml}$ ) was not confirmed. Leucocytosis (up to $11.8 \mathrm{k} / \mu \mathrm{l}$ ) was the only deviation from the norm confirmed in CBC. Haemoglobin, haematocrit and the level of RBC were normal. The level of thyroid-stimulating hormone (TSH) was also normal. Results of the other tests including liver tests, levels of creatinine, urea, glomerular filtration rate (GFR), electrolytes, and ASO were normal. Furthermore, infections with hepatitis B virus (HBV) and hepatitis $\mathrm{C}$ virus (HCV) were not confirmed (Hbs-Ag and anti-HCV samples were non-reactive). Then, the level of anti-nuclear antibodies was determined, however, their presence in serum was not confirmed. Urinalysis revealed rich bacterial flora and 4-5 leucocytes per hpf. During the stay at the ward, the patient also underwent an autologous serum skin test to complete the diagnostics for chronic urticaria. Positive result allowed for confirming the autoimmune background of the urticaria. Due to the extent of urticarial lesions, the treatment initially included parenteral glucocorticosteroids (dexamethasone $8 \mathrm{mg}$ /day for 2 days), antihistamine preparations in maximal doses (cetirizine, and then, loratadine), and anti-leukotriene drugs (montelukast). Next, due to diagnosing autoimmune urticaria, cyclosporine A was included, which is a drug of choice in this type of urticaria, in the dose of $200 \mathrm{mg} /$ day $(2.6 \mathrm{mg} / \mathrm{kg}$ of body weight). Follow-up laboratory tests confirmed adverse reactions of the drug in the form of an increase in creatinine level (from 72.1 to $88.3 \mu \mathrm{mol} / 1$ ), and a decrease in GFR (from 67.2 to $52.6 \mathrm{ml} / \mathrm{min} / 1.73 \mathrm{~m}^{2}$ ), and therefore, the cyclosporine dose was lowered to $100 \mathrm{mg} /$ day $(1.2 \mathrm{mg} / \mathrm{kg}$ of body weight). Thanks to the applied pharmacotherapy, urticarial nodules became absorbed; no new lesions were observed. On owłosionej widoczne było uogólnione przerzedzenie włosów z kilkoma ogniskami łysienia plackowatego w okolicy czołowej i potylicznej o średnicy ok. 3-4 cm (ryc. 3). Płytki paznokciowe rąk i stóp oraz błona śluzowa jamy ustnej bez zmian patologicznych.

W badaniach laboratoryjnych stwierdzono podwyższone stężenie białka C-reaktywnego $(6,9 \mathrm{mg} / 1$ przy normie do 5,0 mg/l), obecność przeciwciał skierowanych przeciwko peroksydazie tarczycowej (anty-TPO 84,8 IU/ml przy normie do 34,0 IU/ml) i przeciwciał przeciwko komórkom okładzinowym żołądka i przeciwko czynnikowi wewnętrznemu (++). Nie były obecne przeciwciała skierowane przeciwko tyreoglobulinie (anty-TG 106,3 IU/ml przy normie do $115 \mathrm{IU} / \mathrm{ml})$. W morfologii krwi z istotnych odchylen od normy stwierdzono leukocytozę (do 11,8 tys./ $\mu 1)$. Wartość hemoglobiny, hematokrytu oraz poziom krwinek czerwonych były w granicach normy. Prawidłowy był również poziom hormonu tyreotropowego (TSH). Wyniki pozostałych badań, do których należały próby wątrobowe, poziom kreatyniny, mocznika, wskaźnik przesączania kłębuszkowego (GFR), elektrolity, ASO, nie przekraczały normy. Nie stwierdzono również zakażenia wirusem zapalenia wątroby typu B (HBV) i C (HCV) (próbki Hbs-Ag oraz anty-HCV niereaktywne). Oznaczono poziom przeciwciał przeciwjądrowych, ale nie stwierdzono ich obecności w surowicy. W badaniu ogólnym moczu wykryto obfitą florę bakteryjną i wykazano 4-5 leukocytów w polu widzenia. W trakcie pobytu na oddziale $\mathrm{u}$ pacjentki wykonano test $\mathrm{z}$ surowicą autologiczną w celu uzupełnienia diagnostyki pokrzywki przewlekłej. Dodatni wynik potwierdził autoimmunologiczne tło pokrzywki. Ze względu na rozległość zmian pokrzywkowych w leczeniu początkowo zastosowano glikokortykosteroidy parenteralnie (deksametazon w dawce $8 \mathrm{mg} /$ dobę przez $2 \mathrm{dni}$ ), preparaty przeciwhistaminowe w dawkach maksymalnych (cetyryzyna, a następnie loratadyna) 
the basis of patient's history, clinical picture, and results of additional tests, the patient was diagnosed with APS-3 and concomitant autoimmune urticaria.

\section{DISCUSSION}

The first reports regarding APS date back to 1929 when a common pathomechanism for the development of hypoparathyroidism and candidiasis was searched in a patient [15]. Today known as APS-1 (or, APECED - autoimmune polyendocrinopathy-candidiasis-ectodermal dystrophy), this is a syndrome including dysfunction of a number of organs that involves co-existence of at least 2 out of the following 3: chronic mucosal candidiasis, hypoparathyroidism and hypocorticoidism $[1,3,8,10,11]$. At present it is known that the spectrum of symptoms can be considerably broader. This group of patients is relatively often diagnosed with the presence of symptoms of autoimmune hepatitis, type 1 diabetes, hypothyroidism, hypogonadism, malignant anaemia, asplenism, alopecia areata, and polyserositis. Furthermore, reports describing concomitant nephritis, arthritis, and retinitis can be found $[1,8,10]$. The disease incidence is estimated at $1: 90000-1: 200000$ cases, whereas in some regions or ethnic groups it may be higher. According to the referenced literature, the incidence rate in females as compared with males equals $5: 1-7: 1$ [8]. Classically, the first symptoms appear in early childhood (usually in the form of mucosal candidiasis), and then subsequent symptoms appear gradually, what makes it difficult to make a final diagnosis. APS-1 is usually inherited in an autosomal recessive way - it is known that about 100 possible mutations of the regulated AIRE gene lie at the bottom of the syndrome. Its expression takes place both in cells lining the thymic medulla as well as peripheral dendritic cells, and it plays an important role in negative selection of autoreactive T-cell clones [8, 9]. The result of expression disorders of the mentioned gene is a presence of various antibodies, whose receptors are found on the target organs, and whose activation disturbs their function.

Type 2 autoimmune polyendocrine syndrome (APS-2, Schmidt's syndrome) occurs with the frequency of 1.4-4.5 cases per 100,000 live births, and simultaneously is the most common in the discussed group [12]. It is believed that this type is even more connected to genetic abnormalities than APS-1. Many studies have confirmed the link with HLA histocompatibility system. APS-2 is usually diagnosed in the third or fourth decade of life, and significantly more often in women. A patient with APS-2 should meet two out of three criteria: Addison's disease, type 1 diabetes, and/or autoimmune disease of the thyroid $[1,3,12,13]$. Due to the phenotype of HLA system, i leki przeciwleukotrienowe (montelukast). Następnie ze względu na rozpoznanie pokrzywki autoimmunologicznej zdecydowano o włączeniu cyklosporyny A, będącej lekiem z wyboru w tym typie pokrzyw$\mathrm{ki}, \mathrm{w}$ dawce $200 \mathrm{mg} /$ dobę $(2,6 \mathrm{mg} / \mathrm{kg}$ m.c.). W kontrolnych badaniach laboratoryjnych stwierdzono działania niepożądane leku w postaci wzrostu stężenia kreatyniny (z 72,1 do 88,3 $\mu \mathrm{mol} / 1)$ i redukcję GFR (z 67,2 do 52,6 ml/min/1,73 $\mathrm{m}^{2}$ ), dlatego zmniejszono dawkę cyklosporyny do $100 \mathrm{mg} /$ dobę $(1,2 \mathrm{mg} /$ $\mathrm{kg}$ m.c.). W wyniku zastosowanej farmakoterapii bąble pokrzywkowe uległy wchłonięciu; nie obserwowano nowych zmian. Na podstawie zebranego wywiadu, obrazu klinicznego oraz wyników badań dodatkowych u pacjentki rozpoznano APS-3 i pokrzywkę autoimmunologiczną.

\section{OMÓWIENIE}

Pierwsze doniesienia dotyczące APS pochodzą z 1929 roku, kiedy to u pacjenta z niedoczynnością przytarczyc i kandydozą doszukiwano się wspólnego patomechanizmu rozwoju obu chorób [15]. Dziś znany jako APS-1 (inaczej APECED - autoimmune polyendocrinopathy-candidiasis-ectodermal dystrophy) zespół dysfunkcji szeregu narządów opisywany jest jako współistnienie przynajmniej 2 z 3 wymienionych chorób: przewlekłej kandydozy śluzówek, niedoczynności przytarczyc i kory nadnerczy [1, 3, $8,10,11]$. Obecnie wiadomo, że spektrum objawów może być znacznie szersze. W tej grupie chorych dość często stwierdzano objawy autoimmunologicznego zapalenia wątroby, cukrzycy typu 1, niedoczynności tarczycy, hipogonadyzmu, anemii złośliwej, asplenizmu, łysienia plackowatego, zapalenia błon surowiczych. Można także znaleźć doniesienia opisujące współistnienie zapalenia nerek, zapalenia stawów bądź siatkówki $[1,8,10]$. Częstość występowania schorzenia szacuje się na 1 : 90 000-1 : 200000 przypadków, przy czym w niektórych regionach i grupach etnicznych może być ona wyższa. Według danych z piśmiennictwa proporcja zapadalności wśród kobiet $\mathrm{w}$ odniesieniu do mężczyzn wynosi 5 : 1$7: 1$ [8]. Klasycznie pierwsze objawy pojawiają się we wczesnym dzieciństwie (zazwyczaj w postaci kandydozy śluzówek), jednak kolejne symptomy dołączają stopniowo, co utrudnia ustalenie ostatecznego rozpoznania. APS-1 jest zazwyczaj dziedziczony autosomalnie recesywnie - wiadomo, że u podłoża zespołu leży ok. 100 możliwych mutacji w genie regulatorowym AIRE. Jego ekspresja zachodzi zarówno w komórkach wyściełających rdzeń grasicy, jak i w obwodowych komórkach dendrytycznych, a odgrywa on istotną rolę $\mathrm{w}$ negatywnej selekcji autoreaktywnych klonów limfocytów T [8, 9]. Efektem zaburzeń ekspresji wspomnianego genu jest obecność różnorod- 
some patients may be at higher risk of developing other autoimmune diseases that include celiac syndrome, alopecia areata, leucoderma, hypogonadism, or malignant anaemia $[12,13]$.

Type 3 APS always occurs with autoimmune hypothyroidism that may co-exist with other diseases $[3,5,6]$. Clinical symptoms usually appear in middle-aged individuals, and more often in women. In Neufeld and Blizzard's classification [7] type 3 APS is divided into 3 sub-types depending on concomitant autoimmune thyroid disease with type 1 diabetes (3A), chronic gastritis or malignant anaemia (3B), and leucoderma, alopecia areata or myasthenia (3C). According to Italian researchers, APS-3 should be termed MAS-3 (multiple autoimmune syndrome) since the spectrum of possible symptoms and diseases is incredibly broad and does not include only incretory glands [6]. About 80 diseases with autoimmune background are discussed within the context of possible pathogenic connection to APS-3; these include: chronic spontaneous urticaria, premature ovarian failure, hypoparathyroidism, malignant anaemia, celiac syndrome, primary biliary cirrhosis, autoimmune hepatitis, cholangitis sclerosans, pancreatitis, vitiligo, alopecia areata, myasthenia, stiff person syndrome, thrombocytopenia, systemic lupus erythematosus, chronic cutaneous lupus erythematosus, mixed connective tissue disease, systemic sclerosis, polymyositis/ dermatomyositis, and vasculitis [3, 5, 6]. Due to rare incidence of this APS type, its frequency has not been precisely determined. In case of APS-3 diagnosis, it is necessary to actively seek other pathological conditions with autoimmune background in order to introduce proper therapy for the patient as soon as possible. In the described case, apart from the routine diagnostics, there was also an autologous serum skin test that allows for assessing the present antibodies against IgE or FceR1 (a high-affinity receptor for IgE). It is a non-specific screening test that evaluates the presence of factors releasing histamine in patient's serum, regardless of their type. The test result is considered positive if the nodule's diameter at the site of patient's serum administration is bigger with at least $1.5 \mathrm{~mm}$ from the nodule's diameter at the site of $0.9 \% \mathrm{NaCl}$ solution administration $[16,17]$. Having confirmed the autoimmunization background of the chronic urticaria resulted in choosing effective therapeutic preparations.

Other combinations of autoimmune diseases that are not covered in the above classifications fall into APS-4 phenotype $[3,14]$.

\section{CONCLUSIONS}

Skin symptoms and conditions should be considered holistically, and within the context of a total clin- nych autoprzeciwciał, których receptory znajdują się na docelowych narządach, a ich aktywacja zaburzy czynność tych narządów.

Autoimmunologiczny zespół niedoczynności wielogruczołowej typu 2 (APS-2, zespół Schmidta) występuje z częstością 1,4-4,5 na 100000 żywych urodzeń i należy do najczęstszych w omawianej grupie [12]. Uważa się, że APS-2 jeszcze silniej niż APS-1 wiąże się z nieprawidłowościami genetycznymi. W wielu badaniach potwierdzono związek z układem zgodności tkankowej HLA. APS-2 zwykle rozpoznawany jest w trzeciej lub czwartej dekadzie życia, znamiennie częściej u kobiet. Pacjent z zespołem APS-2 powinien spełnić dwa z trzech poniższych kryteriów: choroba Addisona, cukrzyca typu 1 i/lub autoimmunologiczna choroba tarczycy $[1,3,12,13]$. Ze względu na fenotyp układu HLA u części chorych występuje zwiększone ryzyko rozwoju innych chorób autoimmunologicznych, do których należą celiakia, łysienie plackowate, bielactwo, hipogonadyzm i anemia złośliwa [12, 13].

Autoimmunologiczny zespół niedoczynności wielogruczołowej typu 3 przebiega zawsze z autoimmunologiczną niedoczynnością tarczycy, która może współistnieć z innymi chorobami [3, 5, 6]. Objawy kliniczne zwykle pojawiają się u osób w średnim wieku, częściej u kobiet. W klasyfikacji Neufelda i Blizzarda [7] APS typu 3 podzielono na kolejne 3 podtypy, w zależności od współistnienia autoimmunologicznej choroby tarczycy z cukrzycą typu 1 (3A), przewlekłym zapaleniem żołądka lub anemią złośliwą (3B) i bielactwem lub łysieniem plackowatym, lub miastenią (3C). Według włoskich badaczy APS-3 należy określać jako MAS-3 (multiple autoimmune syndrome), gdyż spektrum możliwych objawów i schorzeń jest niezwykle szerokie i nie obejmuje wyłącznie gruczołów dokrewnych [6]. Około 80 schorzeń o podłożu autoimmunologicznym jest rozpatrywanych pod względem możliwego związku patogenetycznego z APS-3, należą do nich: przewlekła pokrzywka spontaniczna, przedwczesne wygaśnięcie czynności jajników, niedoczynność przytarczyc, anemia złośliwa, celiakia, marskość żółciowa, autoimmunologiczne zapalenie wątroby, stwardniające zapalenie dróg żółciowych, zapalenie trzustki, bielactwo, łysienie plackowate, miastenia, zespół sztywnego człowieka, trombocytopenia, toczeń rumieniowaty układowy, przewlekły toczeń skórny, mieszana choroba tkanki łącznej, twardzina układowa, zapalenie wielomięśniowe lub skórno-mięśniowe, zapalenie naczyń $[3,5$, 6]. Ze względu na rzadkie występowanie tego typu APS jego częstość nie została dokładnie ustalona. W przypadku rozpoznania APS-3 należy poszukiwać innych stanów patologicznych o podłożu autoimmunologicznym, aby umożliwić pacjentowi jak najszybsze wdrożenie prawidłowego postępowania tera- 
ical picture. The ability to diagnose APS has not only a cognitive value, but also allows for proper monitoring of patients and earlier diagnosis as well as treatment of various autoimmune diseases occurring also in patients' family members.

\section{CONFLICT OF INTEREST}

The authors declare no conflict of interest. peutycznego. W przedstawionym przypadku, poza rutynową diagnostyką, wykonano test $\mathrm{z}$ surowicą autologiczną, który pozwala ocenić obecność autoprzeciwciał skierowanych przeciwko IgE lub FceR1 (receptor o wysokim powinowactwie do IgE). Jest to nieswoisty test przesiewowy, który ocenia obecność czynników uwalniających histaminę w surowicy pacjenta niezależnie od ich rodzaju. Wynik testu uznaje się za dodatni, gdy średnica bąbla w miejscu podania surowicy własnej jest większa co najmniej o 1,5 mm od średnicy bąbla w miejscu podania $0,9 \%$ roztworu $\mathrm{NaCl}[16,17]$. Potwierdzenie autoimmunizacyjnego podłoża pokrzywki przewlekłej wpłynęło na dobór skutecznych preparatów terapeutycznych.

Pozostałe kombinacje schorzeń autoimmunologicznych, nieujęte w powyższych klasyfikacjach, mieszczą się w zakresie APS-4 [3, 14]

\section{WNIOSKI}

Objawy i dolegliwości ze strony skóry należy rozpatrywać holistycznie, uwzględniając całość obrazu klinicznego. Umiejętność diagnozowania APS nie tylko ma wartość poznawczą, lecz także umożliwia prawidłową kontrolę chorych i wcześniejsze rozpoznawanie oraz leczenie różnych chorób autoimmunizacyjnych występujących również u członków ich rodzin.

\section{KONFLIKT INTERESÓW}

Autorzy nie zgłaszają konfliktu interesów.

\section{References}

\section{Piśmiennictwo}

1. Husebye E.S., Anderson M.S., Kämpe O.: Autoimmune polyendocrine syndromes. N Engl J Med 2018, 378, 1132-1141.

2. Cutolo M.: Autoimmune polyendocrine syndromes. Autoimmun Rev 2014, 13, 85-89.

3. Lewiński A., Płaczkiewicz-Jankowska E.: Poliendokrynopatie uwarunkowane autoimmunologicznie. [In:] Choroby wewnętrzne. A. Szczeklik, P. Gajewski (eds.), Wydawnictwo Medycyna Praktyczna, Kraków, 2010, 658-659.

4. Lauger T., Böhm M.: Autoimmunologiczne zespoły niedoczynności wielogruczołowej. [In:] Braun-Falco Dermatologia. W.H.C. Burgdorf, G. Plewig, H.H. Wolff, M. Landthaler (eds.). Wydawnictwo Czelej, Lublin, 2017.

5. Szlendak-Sauer K., Jakubik D., Kunicki M., Skórska J., Smolarczyk R.: Autoimmune polyglandular syndrome type 3 (APS-3) among patients with premature ovarian insufficiency (POI). Eur J Obstet Gynecol Reprod Biol 2016, 203, 61-65.

6. Betterle C., Garelli S., Coco G., Burra P.: A rare combination of type 3 autoimmune polyendocrine syndrome (APS-3) or multiple autoimmune syndrome (MAS-3). Auto Immun Highlights 2014, 5, 27-31.

7. Neufeld M., Maclaren N., Blizzard R.: Autoimmune polyglandular syndromes. Pediatr Ann 1980, 9, 154-162.

8. Guo C.J., Leung P.S.C., Zhang W., Ma X., Gershwin M.E.: The immunobiology and clinical features of type 1 autoimmune polyglandular syndrome (APS-1). Autoimmun Rev 2018, 17, 78-85.

9. Cheng M.H., Fan U., Grewal N.: Acquired autoimmune polyglandular syndrome, thymoma and an AIRE defect. N Engl J Med 2010, 362, 764-766

10. Zaidi G., Bhatia V., Sahoo S.K., Sarangi A.N., Bharti N., Zhang L., et al.: Autoimmune polyendocrine syndrome type 1 in an Indian cohort: a longitudinal study. Endocr Connect 2017, 6, 289-296.

11. Husebye E.S., Perheentupa J., Rautemaa R., Kaempe O.: Clinical manifestation and menagement of patients with autoimmune polyendocrine syndrome type I. J Intern Med 2009, 265, 514-529.

12. Wehbe E., Grant M.E.: Severe hyponatremia and Schmidt's syndrome. Clin Exp Nephrol 2008, 12, 211-214.

13. Rams A., Żółciński M., Zastrzeżyńska W., Polański S., Serafin A., Wilańska J., et al.: Autoimmune polyendocrine syndrome type 2 in patient with severe allergic asthma treated with omalizumab. J Asthma 2018, 55, 1384-1386.

14. Betterle C., Zanchetta R.: Update on autoimmune polyendocrine syndromes (APS). Acta Biomed 2003, 74, 9-33.

15. Schmidt M.B.: Eine biglandulare Erkrankung (Nebennieren und Schilddruuse) bei Morbus Addisoni. Verh Dtsch Ges Pathol $1926,21,212-221$ 
16. Kumar Y.K.K., Bhaskar S., Shankar K.: Comparative study of positive versus negative autologous serum skin test in chronic spontaneous urticaria and its treatment outcome. N Am J Med Sci 2016, 8, 25-30.

17. Boonpiyathad T., Sangasapaviliya A.: Autologous serum and plasma skin test to predict 2-year outcome in chronic spontaneous urticaria. Asia Pac Allergy 2016, 6, 226-235.

Received: 22.08 .2018

Accepted: 14.05 .2019

Otrzymano: $22.08 .2018 \mathrm{r}$.

Zaakceptowano: $14.05 .2019 \mathrm{r}$.

How to cite this article

Kutwin M., Orłowska-Orlik K., Bogaczewicz J., Woźniacka A.: Type 3 autoimmune polyendocrine syndrome (APS) diagnosed in an 87-year-old patient with a concomitant chronic autoimmune urticaria. Dermatol Rev/Przegl Dermatol 2019, 106, 396-404. DOI: https://doi.org/10.5114/dr.2019.88257. 